\title{
Foaming Mechanism of SiC in Steel Slag Foamed Ceramics
}

\author{
Wenqiu FANG, Linjie HOU and Yu LI* \\ State Key Laboratory of Advanced Metallurgy, University of Science and Technology Beijing, Beijing, 100083 China.
}

(Received on May 23, 2020; accepted on October 5, 2020)

\begin{abstract}
Steel slag discharged from steel-making process is a kind of huge secondary resources and hard to be reused. Foamed ceramics are building materials used in the wall insulation and could be a potential goal product for huge amount and high value-added utilization of solid waste. In this paper, foamed ceramics containing 30 wt.\% steel slag and using $\mathrm{SiC}$ as foaming agent were prepared. The effects of SiC content and sintering temperature on its properties were studied, and the difference of foaming mechanism between in steel slag ceramics and in traditional clay ceramics was discussed. The results showed that the foamed ceramics sintered at $1160^{\circ} \mathrm{C}$ had a qualified properties with density of $0.50 \mathrm{~g} / \mathrm{cm}^{3}$ and flexural strength of $2.6 \mathrm{MPa}$, and only $0.1 \mathrm{wt} . \% \mathrm{SiC}$ was added into it, which is an order of magnitude lower than 1-3 wt.\% SiC added in traditional clay foamed ceramic. $\mathrm{SiO}_{2}$ formed from oxidation of $\mathrm{SiC}$ had reacted with $\mathrm{CaO}$ and $\mathrm{Fe}_{2} \mathrm{O}_{3}$ component derived from steel slag to generate new minerals, augite and anorthite. The reactions not only significantly promoted reaction rate of oxidation of $\mathrm{SiC}$ from $4.9 \%$ to $73.5 \%$, but also widened temperature range of the oxidation reaction, contributing to foaming process of ceramics and thereby substantial saving of $\mathrm{SiC}$.
\end{abstract}

KEY WORDS: foamed ceramics; steel slag; foaming mechanism; $\mathrm{CaO} ; \mathrm{Fe}_{2} \mathrm{O}_{3}$.

\section{Introduction}

Steel slag is a kind of huge secondary resources with the amount of above 200 million tonnes in 2019 discharged with output of 1.87 billion crude steel in the world. ${ }^{1)}$ It is difficult to reuse due to its low cementitious reactivity and instability of free- $\mathrm{CaO}$ and $\mathrm{MgO}$. In areas gathering many steel-making factories, utilization of steel slag is worse with most of slag dumped. Steel slags at present was mainly reused in concrete, road pavement and artificial reefs areas. Many new value-added methods were researched in recent years, ${ }^{2)}$ such as converting it into glass ceramics, ${ }^{3)}$ building ceramics, ${ }^{4,5)}$ backfill materials, ${ }^{6)}$ carbonation materials ${ }^{7)}$ or fertilizes $^{8)}$ and recovery of phosphorus. ${ }^{9)}$ In order to improve utilization level of steel slag, exploring new value-added materials with huge application market became important.

Foamed ceramics are widely used in the insulation of building walls. a large amount of closed gas inside the closed hole of the foamed ceramic can effectively prevent the heat exchange on both sides of the wall, and the heat insulation effect can be achieved. Compared with other inorganic thermal insulation material, such as a foamed concrete and mineral wool board, foamed ceramics not only have the advantages in corrosion resistance and high temperature resistance, but also have low thermal conductivity, fireproof, high strength and good durability. As energy-saving build-

\footnotetext{
* Corresponding author: E-mail: leeuu00@sina.com
}

ing was paid more attention, the foamed ceramics will have huge market in the fields of wall insulation, fire insulation isolation and sound insulation areas. ${ }^{10-12)}$

The preparation of traditional foaming ceramics is mostly based on the research of foaming process on silica-alumina based ceramics with raw materials, such as cordierite, clay, kaolin and so on, whose compositions were rich in alumina and silica. Researches on the silica-alumina ceramics is relatively mature, and most of foamed ceramics had silica or silica-alumina based reaction phases, such as quartz, mullite and so on. ${ }^{13-15)}$ After studying a large amount of clay and shale, C.M. Riley ${ }^{16)}$ believed that the suitable chemical composition for foaming was in the range of $53 \mathrm{wt} . \%$ to $79 \mathrm{wt} . \%$ $\mathrm{SiO}_{2}, 10$ wt. $\%$ to 25 wt. $\% \mathrm{Al}_{2} \mathrm{O}_{3}$, and the 13 wt. $\%$ to 26 wt.\% solvent including $\mathrm{Fe}_{2} \mathrm{O}_{3}, \mathrm{CaO}, \mathrm{MgO}, \mathrm{Na}_{2} \mathrm{O}$ and so on.

Steel slag however is characterized by a large content of $\mathrm{CaO}$ and $\mathrm{Fe}_{2} \mathrm{O}_{3}$ with a typical composition of $45 \mathrm{wt} . \% \mathrm{CaO}$, 18 wt. $\% \mathrm{SiO}_{2}, 22$ wt. $\% \mathrm{Fe}_{2} \mathrm{O}_{3}$ (all the element $\mathrm{Fe}$ shown in the form of $\mathrm{Fe}_{2} \mathrm{O}_{3}$ and detected by XRF), and 6 wt.\% $\mathrm{MgO} .{ }^{17)}$ The characteristics makes steel slag difficult to be added with high proportion into traditional silica-alumina based ceramics. In order to mixing more slag with high $\mathrm{CaO}$ and $\mathrm{Fe}_{2} \mathrm{O}_{3}$ content into ceramics, a new $\mathrm{SiO}_{2}-\mathrm{CaO}-$ $\mathrm{MgO}-\mathrm{Al}_{2} \mathrm{O}_{3}-\mathrm{Fe}_{2} \mathrm{O}_{3}$ system ceramics with main crystals of pyroxene and anorthite were researched in recent years. $\mathrm{L}$ $\mathrm{H}$ Zhao et $a .^{4)}$ studied the steel slag ceramic and found that when the proportion of steel slag in ceramics reached 40 wt. $\%$, the ceramic sample with about 12 wt. $\% \mathrm{CaO}$ and 
8 wt. $\% \mathrm{Fe}_{2} \mathrm{O}_{3}$ prepared at $1210^{\circ} \mathrm{C}$ had the maximum bending strength of $143 \mathrm{MPa}$. A. V. Gorokhovsky, et al. ${ }^{18)}$ also added 33-50 wt.\% slag to synthesis ceramic with bending strength of $203 \mathrm{MPa}$ and the ceramics contained perovskite, hollandite, pyrophanite-ilmenite, leucite and pyroxene-like crystalline phases. E. Karamanova et al. ${ }^{19)}$ prepared ceramics with 30 wt. $\%, 50$ wt. $\%$ and 70 wt. $\%$ steel slag in the temperature at $1200-1220^{\circ} \mathrm{C}$ with an elevated crystallinity and formation of anorthite solid solutions and pyroxenes. $\mathrm{X} \mathrm{B} \mathrm{Ai}$, et $a .^{20)}$ prepared steel slag-based ceramics with crystal phases of pyroxenes including augite and diopside at 34 wt. $\%$ addition of steel slag.

As the ceramic from steel slag has its high good mechanical property, preparing foamed ceramics from steel slag is suitable to improve its mechanical properties under a certain porosity. For steel slag based ceramics system contains high $\mathrm{CaO}$ and $\mathrm{Fe}_{2} \mathrm{O}_{3}$ content, its liquid phase will be more easily formed, ${ }^{21)}$ which is beneficial to the expansion of the ceramic under the action of gas. However, as the content of $\mathrm{CaO}$ and $\mathrm{Fe}_{2} \mathrm{O}_{3}$ increases, the viscosity of the liquid phase at a high temperature decreases, which is adverse to the residence of the gas inside the sample. ${ }^{22)}$ Therefore, it is essential for preparation of a high-quality foamed ceramics that the temperature of gas generating for a foaming agent matches the temperature of forming a liquid phase with a suitable viscosity in the steel slag ceramics.

$\mathrm{SiC}$ is a suitable foaming agent and widely applied into practices. It was found ${ }^{23)}$ that $\mathrm{SiC}$ can continue to oxidize and release gas in a wide temperature range from $570^{\circ} \mathrm{C}$ to even above $1200^{\circ} \mathrm{C}$. The wide temperature range provides a wide adaptability for different ceramics. Foaming mechanism of $\mathrm{SiC}$ as a foaming agent have been researched in recent years. C C Jiang et al. $^{24)}$ prepared foamed ceramics containing uniform closed pores from granite scraps and minor clay tailings as the main raw materials with the addition of $1.0 \mathrm{wt} . \% \mathrm{SiC}$. It was mentioned that $\mathrm{SiC}$ effectively acted as foaming agent due to the oxidation reactions and then the formed $\mathrm{CO}_{2}$ and $\mathrm{CO}$ gas stayed in the melt with equilibrium. Yonglin $\mathrm{Zhang}^{25)}$ studied the effect of different amount of $\mathrm{SiC}$ addition on the foaming performance. Its results showed that $\mathrm{SiC}$ produced $\mathrm{CO}_{2}$ by self-oxidation with high efficiency to play a role in foaming process. But $\mathrm{SiC}$ would form a dense and collectively bonded $\mathrm{SiO}_{2}$ film on the surface under high temperature, which made it difficult for oxygen to diffuse into the interior of $\mathrm{SiC}$ and resulted a large proportion of unreacted $\mathrm{SiC}$ in foamed ceramics even at a high sintering temperature of over $1200^{\circ} \mathrm{C}^{26)}$ For improving oxidation of $\mathrm{SiC}$ to release more gas, increasing fineness of $\mathrm{SiC}$ from 200-mesh sieve to 500-mesh or even 1000 -mesh sieve for obtaining an huge superficial areas to react with oxygen was traditionally applied into practices but its cost was significantly increased as well. Another method was mixing $\mathrm{CaO}$ with $\mathrm{SiC}$ to promote its oxidation. Researcher on foamed ceramics from porcelain tile powder revealed that the addition of a small amount of $\mathrm{CaO}$ accelerated foaming properties of ceramics, while its foaming rate was notably inhibited by an increasing formation of anorthite. ${ }^{27)}$

The above researches all focused on traditional silicaalumina system ceramics, but the slag based ceramics has a composition of $\mathrm{CaO}+\mathrm{Fe}_{2} \mathrm{O}_{3}$ larger than $20 \mathrm{wt} . \%$, and the high proportion of $\mathrm{CaO}$ and $\mathrm{Fe}_{2} \mathrm{O}_{3}$ component could have significantly effect on oxidation and gas releasing process of SiC. Research on the foamed mechanism of ceramics was thereby important for preparation of foamed ceramics from $\mathrm{CaO}$ and $\mathrm{Fe}_{2} \mathrm{O}_{3}$ rich slag.

In the paper, the effects of the amount of $\mathrm{SiC}$ addition from 0 to $0.3 \%$ and the sintering temperature on the steel slag foamed ceramics from $1110^{\circ} \mathrm{C}$ to $1160^{\circ} \mathrm{C}$ were studied. And the foaming mechanism in this process were discussed. The innovation aspect of the work was to reveal that reactions between $\mathrm{CaO}$ (or $\mathrm{Fe}_{2} \mathrm{O}_{3}$ ) and $\mathrm{SiC}$ promote oxidations and gas releasing of $\mathrm{SiC}$, which would significantly reduce addition of $\mathrm{SiC}$ by an order of magnitude lower than that in traditional silica-alumina foamed ceramic. The objective was to provide a theoretical basis for reducing the amount of $\mathrm{SiC}$ addition and optimizing of the foam process. XRD and TG-DSC analysis was the main means used in the study. The change of the mass of the samples and the temperature of the main reaction, especially for oxidization reaction of $\mathrm{SiC}(s)+2 \mathrm{O}_{2}(g) \rightarrow \mathrm{SiO}_{2}(s)+\mathrm{CO}_{2}(g)$ can be obtained by the TG-DSC curve. Then the results of XRD were combined to ensure the different reaction process related to $\mathrm{SiC}$ between in slag ceramics and in clay ceramics. The foaming mechanism of $\mathrm{SiC}$ in steel slag foamed ceramics was further discussed.

\section{Experiments}

\subsection{Raw Materials}

The raw materials used in the study were Laiwu Steel Slag, talc and two clays. Clay 1 was from Zhangqiu and clay 2 was from Laiyang. The raw materials were crushed and ground until they could be passed through a 200-mesh sieve, then dried in a drying oven at $105^{\circ} \mathrm{C}$. Their compositions were examined by X-ray fluorescence spectrometer (XRF1800). The results are shown in Table 1. Chemical analysis was further employed for steel slag to detect compositions containing different iron valence in according to Chinese national standard. ${ }^{28-30)}$

As can be seen from Table 1, the main characteristics of the steel slag are that it contains a large amount of $\mathrm{CaO}$ and iron oxide but less $\mathrm{SiO}_{2}$ and $\mathrm{Al}_{2} \mathrm{O}_{3}$. The results by chemical analysis shows that $\mathrm{Fe}$ in steel slag existed in the form of 17.8 wt. $\%$ TFe, 0.8 wt. $\%$ MFe, 12.7 wt. \% FeO, 10.2 wt.\% $\mathrm{Fe}_{2} \mathrm{O}_{3}{ }^{28-30)}$ The two clays are added as a supplement to $\mathrm{SiO}_{2}$ and $\mathrm{Al}_{2} \mathrm{O}_{3}$. The talc mainly provides $\mathrm{MgO}$ for the ceramic, which is beneficial for generating augite. And augite can increase the strength of the ceramic samples.

Table 1. The chemistry composition of raw materials and ceramics S0 (wt.\%).

\begin{tabular}{lrrrrrrr}
\hline \multicolumn{1}{c}{ wt.\% } & $\mathrm{SiO}_{2}$ & $\mathrm{Al}_{2} \mathrm{O}_{3}$ & $\mathrm{CaO}$ & $\mathrm{MgO}$ & $\mathrm{Fe}_{2} \mathrm{O}_{3}$ & $\mathrm{Na}_{2} \mathrm{O}$ & $\mathrm{K}_{2} \mathrm{O}$ \\
\hline Steel slags & 19.6 & 2.9 & 42.9 & 4.1 & 23.1 & - & 0.1 \\
Talc & 37.0 & 13.8 & 2.6 & 26.0 & 4.2 & 0.3 & 0.9 \\
Clay 1 & 60.9 & 22.7 & 1.8 & 0.8 & 7.9 & 0.2 & 4.0 \\
Clay 2 & 70.4 & 15.9 & 4.1 & 4.3 & 2.2 & 0.3 & 2.3 \\
S0 & 48.7 & 15.3 & 14.5 & 3.6 & 11.4 & 0.1 & 2.4 \\
\hline
\end{tabular}




\subsection{Preparation of Samples}

Composition of steel slag ceramic was shown in Table 1 and proportion of its raw materials was shown in Table 2, numbered S0. On the basis of it, $0.1 \mathrm{wt} . \%$, and $0.3 \mathrm{wt} . \%$ of $\mathrm{SiC}$ were added, and respectively numbered $\mathrm{S} 1$ and $\mathrm{S} 3$. Each batch of raw materials were mixed and wet ground in a pot mill for $20 \mathrm{~min}$ to obtain homogenization. After being screened by 200 -mesh sieve and dried at $110^{\circ} \mathrm{C}$ for $10 \mathrm{~h}$, the raw materials were granulated to small particles with 6-8 wt.\% moisture. The green body having a size of $50 \mathrm{~mm} \times 5 \mathrm{~mm} \times 5 \mathrm{~mm}$ was prepared under a pressure of 15-20 MPa. The dried green body was fired at different sintering temperature in an electrically operated laboratory furnace, heated at a heating rate of $5^{\circ} \mathrm{C} / \mathrm{min}$ to a sintering temperature and maintained for $1 \mathrm{~h}$, followed by natural cooling in the furnace to ambient temperature.

Only steel slag and $\mathrm{SiC}$ were mixed to further study the mechanism of the reaction. Theoretically, the complete consumption of $\mathrm{Al}_{2} \mathrm{O}_{3}, \mathrm{CaO}, \mathrm{MgO}$ and $\mathrm{Fe}_{2} \mathrm{O}_{3}$ by $100 \mathrm{~g}$ steel slag required a total of $1.705 \mathrm{~mol} \mathrm{SiO}_{2}, 100 \mathrm{~g}$ steel slag contains $0.7 \mathrm{~mol} \mathrm{SiO}_{2} .1 .005 \mathrm{~mol} \mathrm{SiO}_{2}$ thereby needs to be added through $\mathrm{SiC}, 40.2 \mathrm{~g}$ of $\mathrm{SiO}_{2}$ produced by the complete reaction of $\mathrm{SiC}$, and the mass ratio with steel slag is thereby $5: 2$. The sample that steel slag to $\mathrm{SiC}$ of $5: 2$ were mixed firstly and then sintered at $1200^{\circ} \mathrm{C}$. It was denoted as $\mathrm{S}-\mathrm{MS}$. At the same time, steel slag and $\mathrm{SiC}$ were sintered at $1200^{\circ} \mathrm{C}$ separately, then mixed in the same ratio as a reference. This sample was denoted as S-SM. Similarly, clay was studied as a kind of typical silica-alumina material with 54.3 wt. $\% \mathrm{SiO}_{2}, 32.9$ wt. $\% \mathrm{Al}_{2} \mathrm{O}_{3}, 2.2$ wt. $\% \mathrm{CaO}$ and 3.9 wt.\% $\mathrm{Fe}_{2} \mathrm{O}_{3}$. The sample in the same ratio was mixed firstly and then sintered, the sintered sample was denoted as C-MS, and the sample which was sintered separately and then mixed was denoted as C-SM. In order to ensure the effects of typical components in steel slag on the foaming process of $\mathrm{SiC}, \mathrm{CaO}$ (chemically pure) and $\mathrm{Fe}_{2} \mathrm{O}_{3}$ (chemically pure) were mixed with $\mathrm{SiC}$ separately. Due to obtain the same molar ratio of 1:1 between $\mathrm{Ca}: \mathrm{Si}$ and $\mathrm{Fe}: \mathrm{Si}$ in respectively mixtures, the mass ratio of $\mathrm{CaO}$ to $\mathrm{SiC}$ was $7: 5$ and $\mathrm{Fe}_{2} \mathrm{O}_{3}$ to $\mathrm{SiC}$ was $2: 1$.

\subsection{Material Characterization Techniques}

Thermal gravimetric-differential scanning calorimeter analysis (TG-DSC; USA) was used to study the temperature of the phase change and the thermal reaction. The test condition of temperature range was from ambient temperature to $1300^{\circ} \mathrm{C}$ with a heating rate of $10^{\circ} \mathrm{C} / \mathrm{min}$ in air atmosphere. The particle diameter distribution of $\mathrm{SiC}$ was determined by laser particle size distribution analyzer (SEISHIN, Inc., Japan). Crushed powder samples were flattened and scanned by an X-ray diffraction instrument (XRD; M21X, MAC Science Co., Ltd., Japan) to test the composition of the sample. Surface morphology of the sample was observed by using an optical microscope (Leica Microsystems CMS GmbH, Germany).

Table 2. The weight ratio of S0 (wt.\%).

\begin{tabular}{ccccc}
\hline Sample & Steel slag & Talc & Clay 1 & Clay 2 \\
\hline S & 30 & 5 & 50 & 15 \\
\hline
\end{tabular}

Then, several formulas were used to calculate some parameters. Flexural strength of the sintered samples was calculated by Eq. (1).

$$
R=\frac{3 \times F \times L}{2 \times b \times h^{2}}
$$

where $R$ is the flexural strength (MPa); $F$ is the load (N) tested by a ceramic tile flex; $L$ is the fulcrum spacing $(\mathrm{mm})$, $b$ is the width ( $\mathrm{mm})$ and $h$ is the height $(\mathrm{mm})$ tested by a digital vernier caliper.

The bulk density was calculated by Eq. (2).

$$
D_{V}=\frac{m_{1}}{m_{2}-m_{3}}
$$

where $D_{V}$ is the bulk density $\left(\mathrm{kg} / \mathrm{m}^{3}\right) ; m_{1}$ is the dry weight of the sample $(\mathrm{kg}) ; m_{2}$ is the weight of the saturated sample in the air $(\mathrm{kg}) ; m_{3}$ is the weight of the saturated sample in water $(\mathrm{kg})$.

For preparing the saturated sample, CXX-A type ceramic water absorption vacuum device (Ningxia Machinery Co., Ltd) was used.

\section{Results}

\subsection{Thermal Analyses of Raw Materials}

The results of particle diameter distribution of $\mathrm{SiC}$ were shown in Fig. 1. The particle diameter was distributed from $1.29 \mu \mathrm{m}$ to $32.78 \mu \mathrm{m}$, where diameter of $50 \%$ particle of $\mathrm{SiC}$ was below $6.923 \mu \mathrm{m}$. And its specific surface area was $1.386 \mathrm{~m}^{2} / \mathrm{cm}^{3}$.

In order to obtain the characterization of raw materials, the thermal analyses of $\mathrm{SiC}$ and steel slag from ambient temperature to $1300^{\circ} \mathrm{C}$ in air atmosphere had been measured by TG-DSC method. The results are shown in Fig. 2.

The theoretical reaction of $\mathrm{SiC}$ under sufficient $\mathrm{O}_{2}$ conditions is

$$
\mathrm{SiC}(s)+2 \mathrm{O}_{2}(g) \rightarrow \mathrm{SiO}_{2}(s)+\mathrm{CO}_{2}(g)
$$

Oxidation of $\mathrm{SiC}$ results in 50 wt.\% mass gained after $\mathrm{SiO}_{2}$ formed and $\mathrm{CO}_{2}$ escaped according to the calculation from Eq. (3). Actually, it can be seen from Fig. 2 that the mass increased only 2.2 wt. $\%$ until $1300^{\circ} \mathrm{C}$. Meanwhile, $\mathrm{SiC}$ was relatively stable before $1016^{\circ} \mathrm{C}$, and increased its

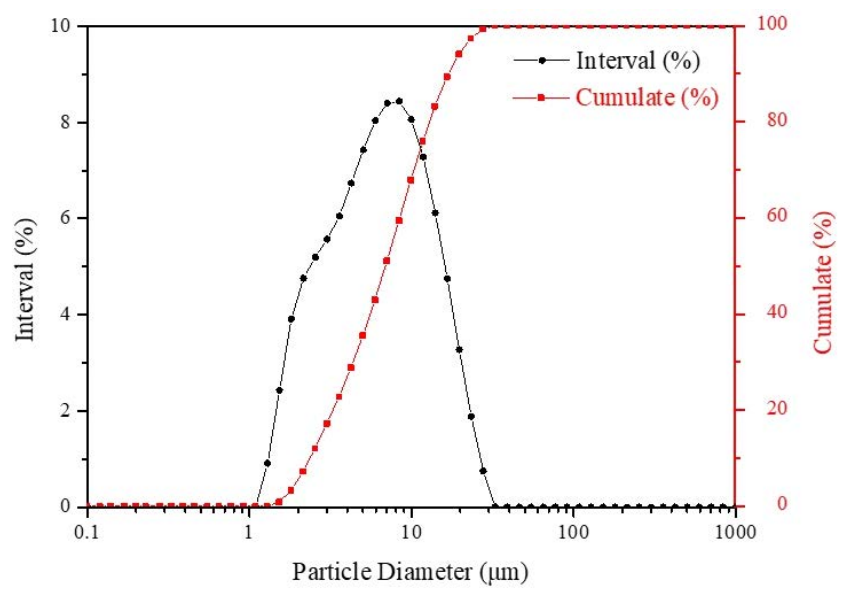

Fig. 1. The particle diameter distribution of SiC. (Online version in color.) 
(a)

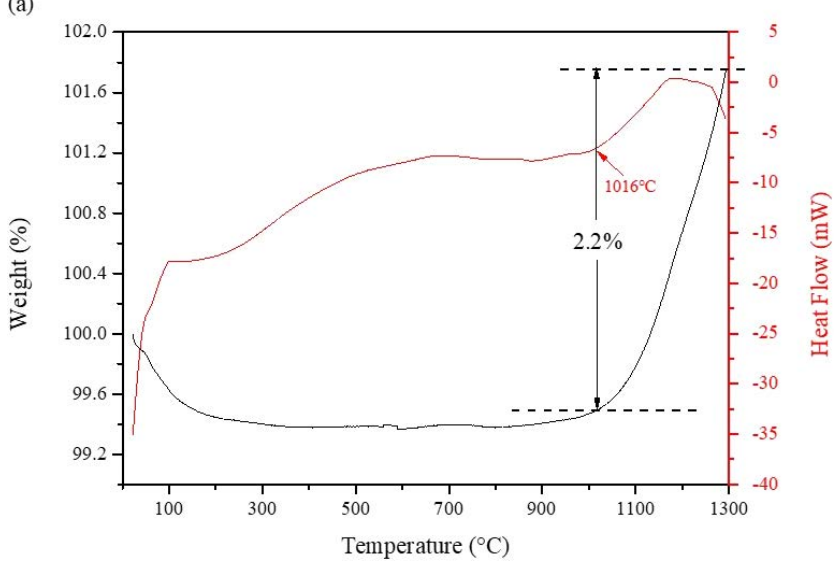

(b)

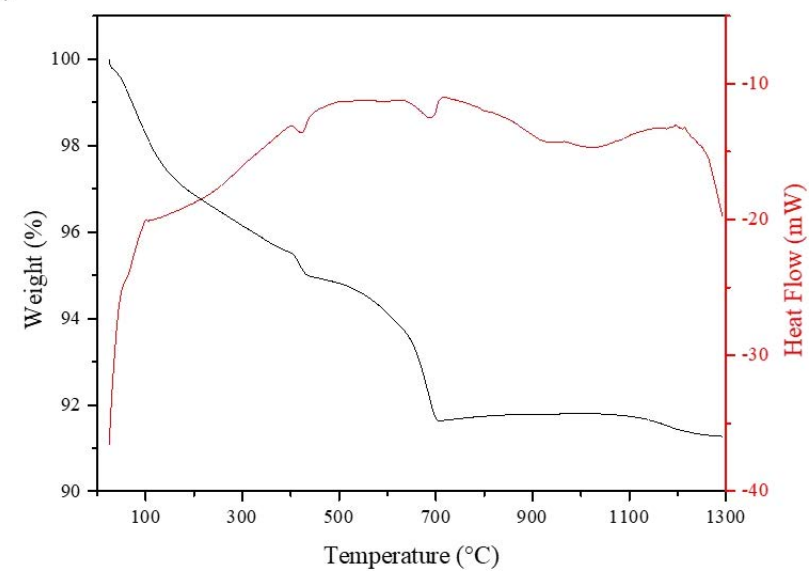

(c)

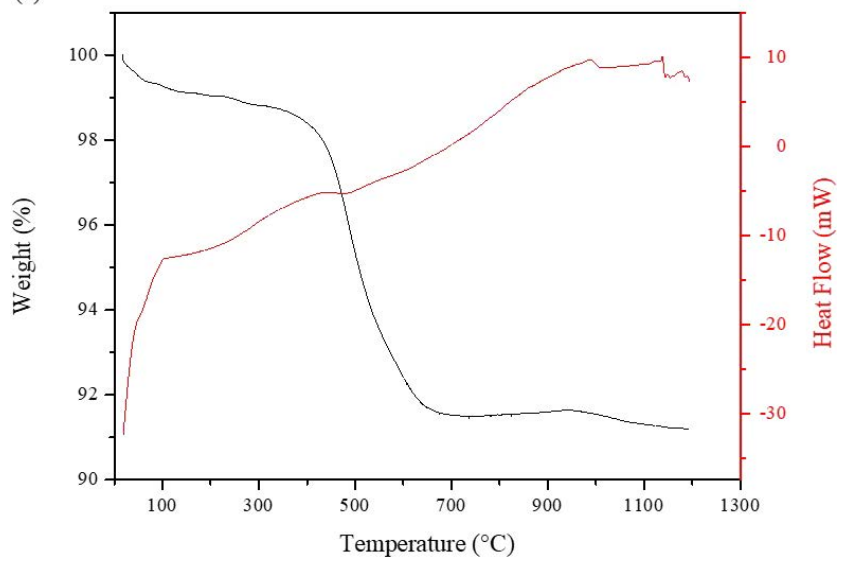

Fig. 2. The TG-DSC result of (a) SiC, (b) steel slag and (c) clay. (Online version in color.)

mass rapidly after $1016^{\circ} \mathrm{C}$ with an obvious reaction peak. After $1200^{\circ} \mathrm{C}$, the mass was still increased, but the reaction rate had been slowed down. Therefore, it was chosen to sinter $\mathrm{SiC}$ at $1200^{\circ} \mathrm{C}$ and the XRD results were shown in Fig. 3. It can be proved from Fig. 3 that a large amount of $\mathrm{SiC}$ remained unreacted with little amount of $\mathrm{SiO}_{2}$ produced.

\subsection{Properties of the Foamed Ceramics}

The shrinkage, water absorption and flexural strength of S0 sintered at different temperatures were shown in Fig. 4. It can be seen that the temperature range of $1100-1130^{\circ} \mathrm{C}$ was the densification stage of the ceramic and its liquid phase appeared after $1120^{\circ} \mathrm{C}$ due to dramatic changes of its water absorption and flexural strength and become excess

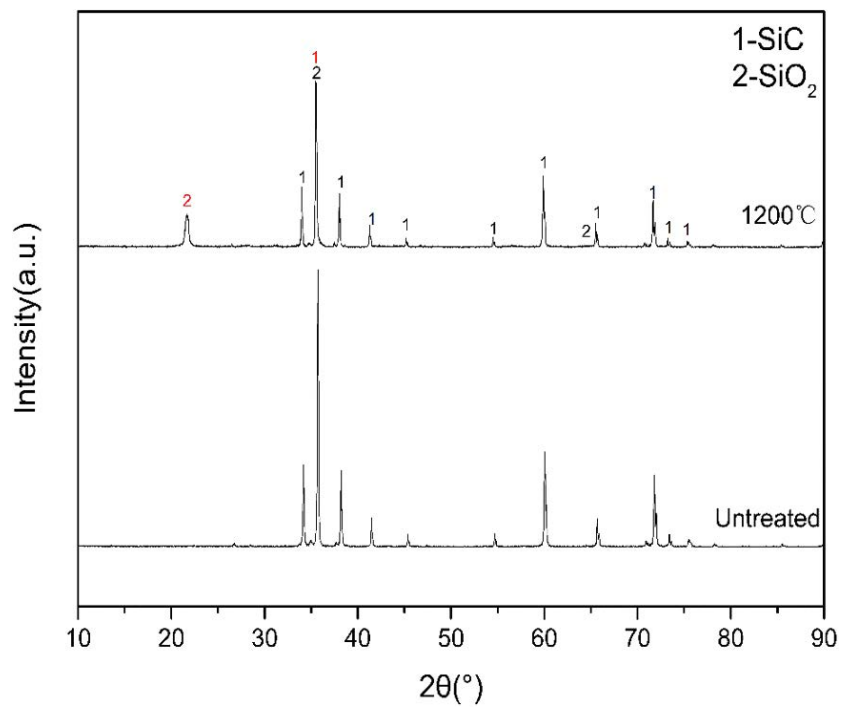

Fig. 3. The XRD result of untreated $\mathrm{SiC}$ and $\mathrm{SiC}$ sintered at $1200^{\circ} \mathrm{C}$ and the special red number meant the strongest or/and characteristic peak of a crystal phase. (Online version in color.)

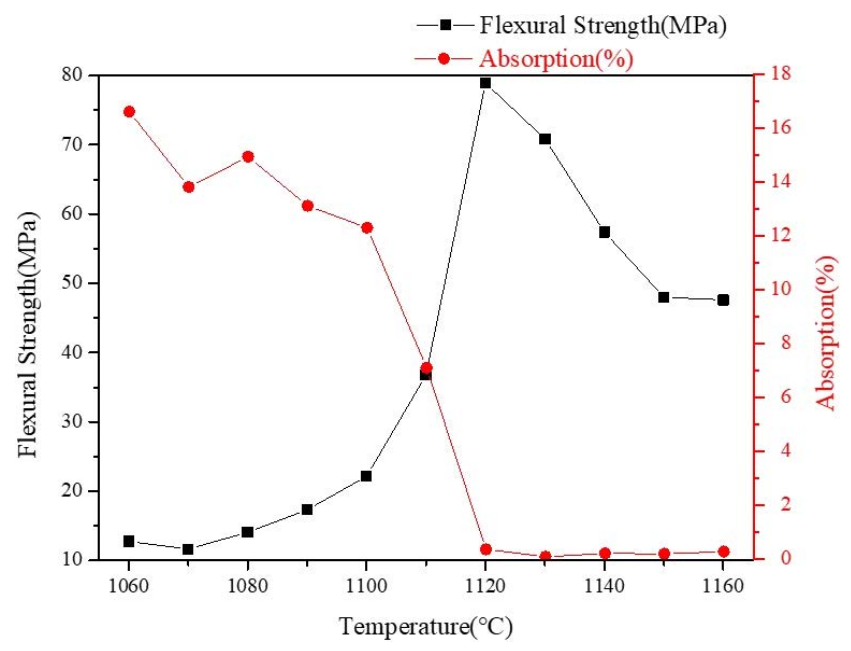

Fig. 4. Water absorption and flexural strength of S0 sintered at different temperatures. (Online version in color.)

after $1130^{\circ} \mathrm{C}$ for decrease of its flexural strength. The temperature range was just fallen into the temperature range of oxidation of $\mathrm{SiC}$. It was beneficial for the foaming process.

As shown in Fig. 5, S1 and S3 had flexural strength of near $50 \mathrm{MPa}$ higher than that of $\mathrm{S} 0$ at $1110^{\circ} \mathrm{C}$, but had significant lower flexural strength than $\mathrm{S} 0$ when they were fired at and above $1120^{\circ} \mathrm{C}$. Oxidation of $\mathrm{SiC}$ started at $1016^{\circ} \mathrm{C}$ which was indicated in Fig. 2. Moreover, ceramics fell into a liquid sintering process above $1120^{\circ} \mathrm{C}$ as shown in Fig. 4. Gas releasing thereby occurred simultaneous with liquid sintering process for $\mathrm{S} 1$ and $\mathrm{S} 3$ after $1120^{\circ} \mathrm{C}$, which was contributed to the decrease of strength of S1 and S3 fired at above $1120^{\circ} \mathrm{C}$.

The bulk density is an important part of the properties of foamed ceramics. It can be seen from Fig. 6 that S1 and S3 were slightly smaller than S0 during firing temperature below $1130^{\circ} \mathrm{C}$, and they decreased rapidly under the temperature above $1130^{\circ} \mathrm{C}$. Formation of a large quantity of liquid in ceramics promoted foaming process of S1 and S3, which was contributed to the rapid decrease in density. The 


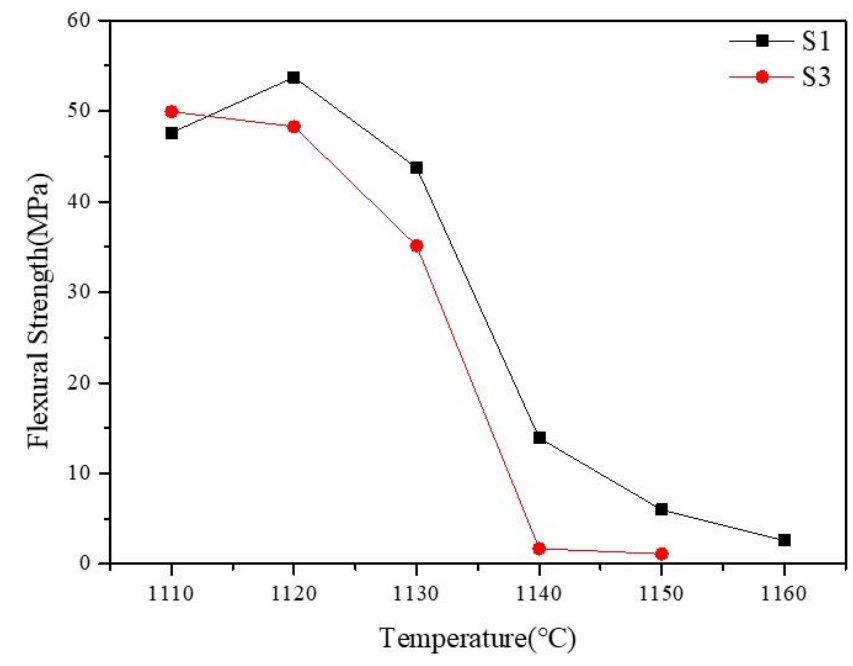

Fig. 5. The flexural strength of $\mathrm{S} 1$ and $\mathrm{S} 3$ sintered at different temperature. (Online version in color.)

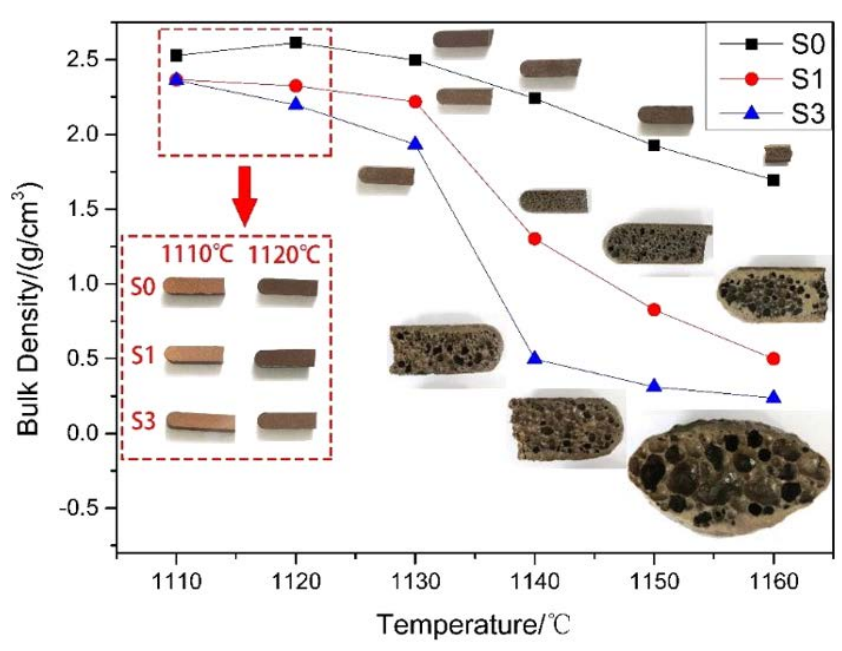

Fig. 6. The bulk density and the view of three batches of samples at the same scale. (Online version in color.)

bulk density was reduced under $1 \mathrm{~g} / \mathrm{cm}^{3}$ at $1150^{\circ} \mathrm{C}$ for $\mathrm{S} 1$ and at $1140^{\circ} \mathrm{C}$ for $\mathrm{S} 3$. The presence of pores caused to the decrease of the strength especially after $1130^{\circ} \mathrm{C}$, as was shown in Fig. 5, which was in consistence with the trend of density reduction in Fig. 6.

The foamed ceramic S1 had high flexural strength of 6.0 Mpa, density of $0.83 \mathrm{~g} / \mathrm{cm}^{3}$ and specific strength of $7229 \mathrm{~N} \cdot \mathrm{m} / \mathrm{kg}$ at firing temperature of $1150^{\circ} \mathrm{C}$, and its density, flexural strength and specific strength decreased to 0.50 $\mathrm{g} / \mathrm{cm}^{3}, 2.60 \mathrm{MPa}$ and $5200 \mathrm{~N} \cdot \mathrm{m} / \mathrm{kg}$ when it was sintered at $1160^{\circ} \mathrm{C}$. S3 fired at $1150^{\circ} \mathrm{C}$ had a similar density, flexural strength and specific strength of $0.31 \mathrm{~g} / \mathrm{cm}^{3}, 1.11 \mathrm{MPa}$ and $3581 \mathrm{~N} \cdot \mathrm{m} / \mathrm{kg}$. The density of foaming ceramic insulation board in the external wall insulation system is generally $\leq 0.28 \mathrm{~g} / \mathrm{cm}^{3}$, flexural strength is $\geq 0.6 \mathrm{mpa}$, specific strength is greater than $2100 \mathrm{~N} \cdot \mathrm{m} / \mathrm{kg}$. All the samples can meet the strength requirements of foaming ceramic insulation board. It is induced that larger amount of $\mathrm{SiC}$ in ceramics decreased the firing temperature for obtaining similar properties. Moreover, it is interesting that the addition of $\mathrm{SiC}$ into it was only $0.1-0.3 \mathrm{wt} . \%$, which is an order of magnitude lower than 1-3 wt.\% addition of $\mathrm{SiC}$ in traditional (a)

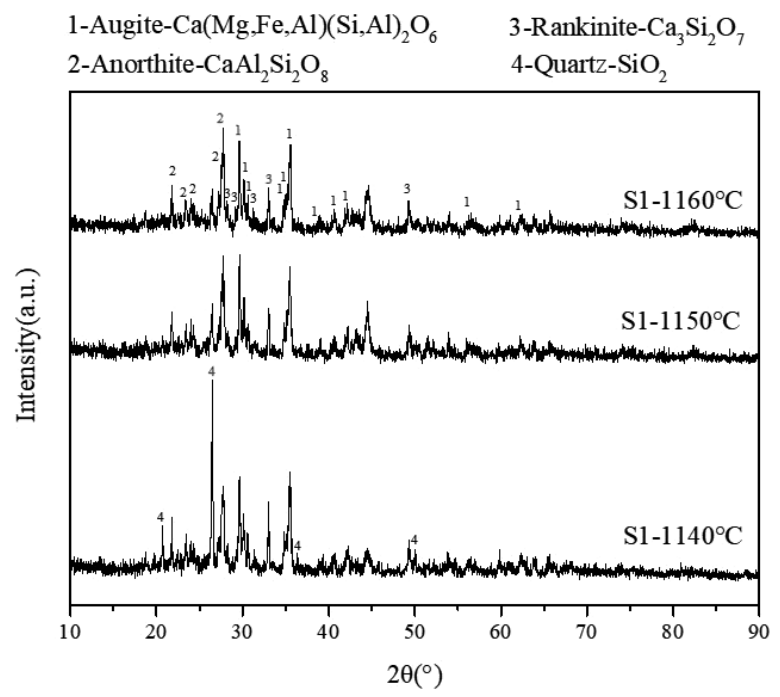

(b)
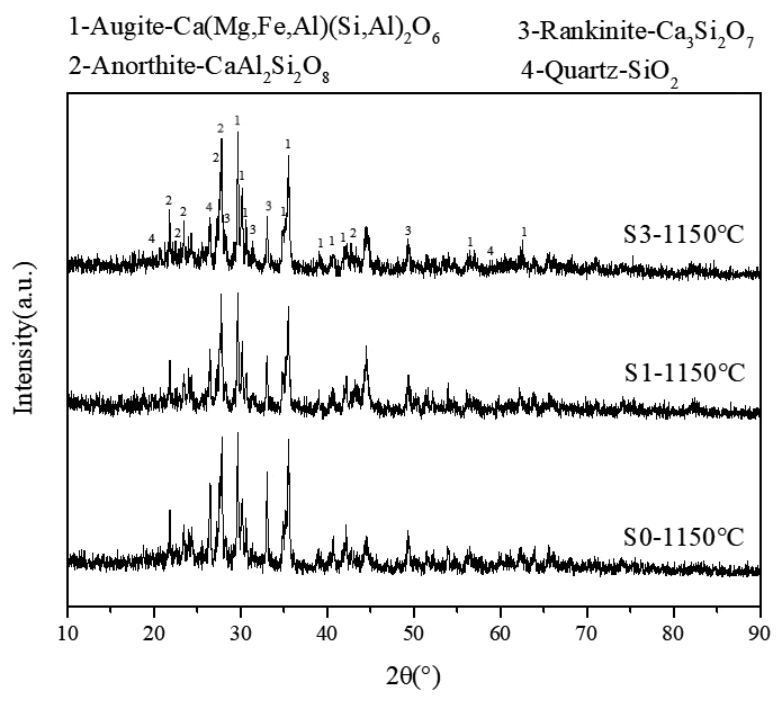

Fig. 7. The XRD results of (a) $\mathrm{S} 1$ sintered at $1140^{\circ} \mathrm{C}, 1150^{\circ} \mathrm{C}$, $1160^{\circ} \mathrm{C}$, (b) S0, S1, S3 sintered at $1150^{\circ} \mathrm{C}$, and the special red number meant the strongest or/and characteristic peak of a crystal phase.

silica-alumina foamed ceramic. ${ }^{24-27)}$

Figures 7(a) and 7(b) showed the XRD results of S1 sintered at $1140^{\circ} \mathrm{C}, 1150^{\circ} \mathrm{C}, 1160^{\circ} \mathrm{C}$ and $\mathrm{S} 0, \mathrm{~S} 1, \mathrm{~S} 3$ sintered at $1150^{\circ} \mathrm{C}$. It can be seen from Fig. 7(a) that a large amount of $\mathrm{SiO}_{2}$ generated in ceramic sintered at $1140^{\circ} \mathrm{C}$. With the increase of temperature, the characteristic peaks of quartz and rankinite decreased and that of anorthite and augite increased accordingly. The results of S1 and S3 were similar in Fig. 7(b). Compared with S0, the characteristic peaks of quartz and rankinite decreased as well. It was difficult to find the existence of $\mathrm{SiC}$ in the XRD results due to the extremely small amount addition. But it can be inferred from the decrease of quartz and rankinite and the increase of anorthite and augite that $\mathrm{CaO}$ and $\mathrm{SiO}_{2}$ were more converted in the $\mathrm{S} 1$ and $\mathrm{S} 3$ to be converted into anorthite and augite. It was indicated that $\mathrm{CaO}$ played a crucial role in promoting the reaction of $\mathrm{SiC}$.

Microstructure of S1 was studied and shown in Fig. 8. It can be seen that the pores didn't formed at $1130^{\circ} \mathrm{C}$ and then became larger and larger with the increasing temperature. The shape of the pores at $1140^{\circ} \mathrm{C}$ was not very regular, and pore walls hadn't been formed obviously. Starting from 

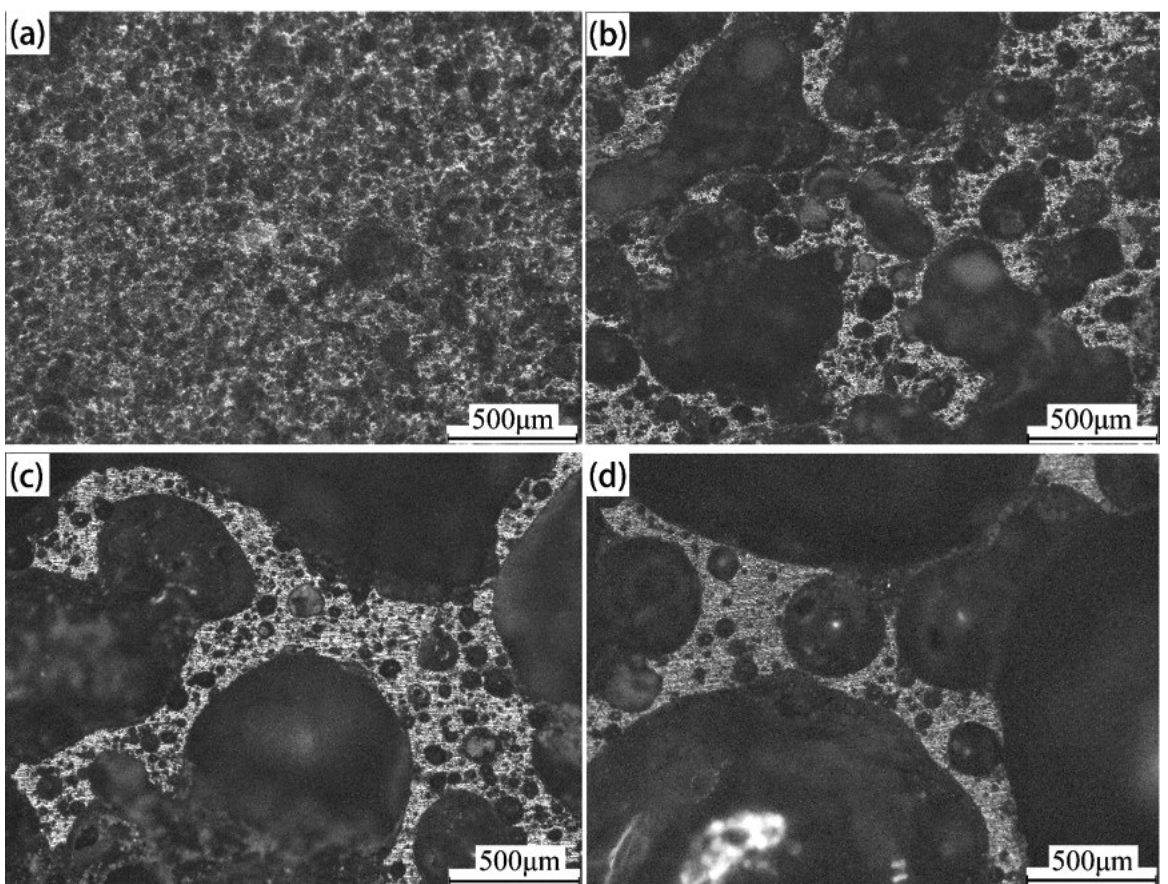

Fig. 8. The microstructure of S1 sintered at (a) $1130^{\circ} \mathrm{C}$, (b) $1140^{\circ} \mathrm{C}$, (c) $1150^{\circ} \mathrm{C}$ and (d) $1160^{\circ} \mathrm{C}$.

$1150^{\circ} \mathrm{C}$, the shape and size of the main pores tended to be regular, and the pore walls could be distinguished obviously. At the same time, there were also some small holes in the pore walls, and smaller pores were distributed around the pore wall. At $1160^{\circ} \mathrm{C}$, the size of the main pores was further increased and the size of the pores on the pore wall was simultaneously increased. It was also observed that the pores in the pore walls had a tendency to merge toward the main pores. Such large and inhomogeneous pores would be adverse to its mechanical but be beneficial to its heatinsulation and bulk density properties.

These features indicated that the generation of gas was a continuous process. The gas generated firstly stayed inside the body to form pores, afterwards moved slowly in the body with a certain viscosity and finally synthesized large pores. During the cooling process, the small pores that did not synthesize large pores stayed in the solidified body. Since the viscosity of the body lowered under the raising temperature, the diffusion of the pores became higher and the pores were easier to merge into large pores.

\section{Discussion}

\subsection{Comparison of Foaming Mechanism between Slag Ceramic and Clay Ceramic}

Low reaction rate for $\mathrm{SiC}$ was considered to be formation of the $\mathrm{SiO}_{2}$ film which is coated on the outer surface of $\mathrm{SiC}$ particles to prevent its further reaction. In order to promote the reaction rate of $\mathrm{SiC}$, it is necessary to destroy the surface of $\mathrm{SiO}_{2}$ film for continuous reaction between the internal $\mathrm{SiC}$ and $\mathrm{O}_{2}$. Steel slag with high content of $\mathrm{CaO}$ and $\mathrm{Fe}_{2} \mathrm{O}_{3}$ is a cheaper additive for reaction with $\mathrm{SiO}_{2}$. For further study of the reaction between slag and $\mathrm{SiC}$, TG-DSC and XRD of samples were conducted, and samples related to clay and $\mathrm{SiC}$ as a reference were conducted as well.

TG-DSC curves of mixture of steel slag and $\mathrm{SiC}$ were shown in Fig. 9. Compared with respective curves of $\mathrm{SiC}$

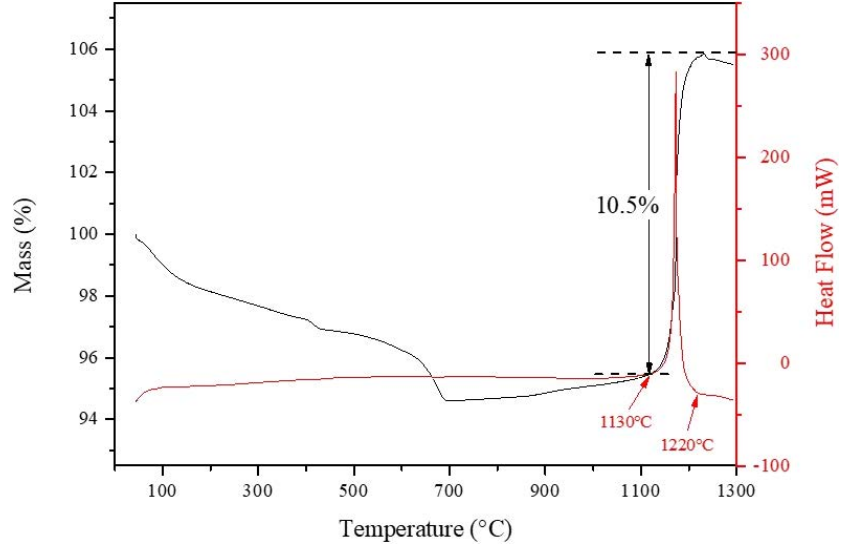

Fig. 9. The TG-DSC result of mixture of steel slag and $\mathrm{SiC}$ with mass ratio of 5:2. (Online version in color.)

and steel slag in Figs. 2(a) and 2(b), it was found that the curves of mixture were not their simple superimposition. An exothermic peak appeared obviously from firing temperature of $1130^{\circ} \mathrm{C}$ to $1220^{\circ} \mathrm{C}$, corresponding to mass gain of about 10.5 wt. $\%$, which was significantly different from the curves of both steel slag and SiC.

Compared with TG-DSC curves of $\mathrm{SiC}$ and clay in Figs. 2(a) and 2(c), curves of mixture of clay and SiC (in Fig. 10) however were almost the superposition of curves of clay and $\mathrm{SiC}$ with feature of a mass lost from $400^{\circ} \mathrm{C}$ to $600^{\circ} \mathrm{C}$ due to high volatile content of clay and a mass gain above $1016^{\circ} \mathrm{C}$ due to oxidization of $\mathrm{SiC}$. An exothermic peak appeared from firing temperature of $1041^{\circ} \mathrm{C}$ to $1300^{\circ} \mathrm{C}$, corresponding to mass gain of 0.7 wt. $\%$, which was almost resulted from oxidization of $\mathrm{SiC}$. As oxidization of $\mathrm{SiC}$ causes 2.2 wt.\% gain in mass, the mixture with $2 / 7 \mathrm{SiC}$ would theoretically be $0.63 \mathrm{wt} . \%$, approaching the mass gain of $0.7 \mathrm{wt} . \%$.

The same results as TG-DSC curves took place on XRD patterns. As shown in Figs. 11 and 12, S-MS (mixture of raw steel slag and $\mathrm{SiC}$ ) was sintered at $1200^{\circ} \mathrm{C}$, and it 


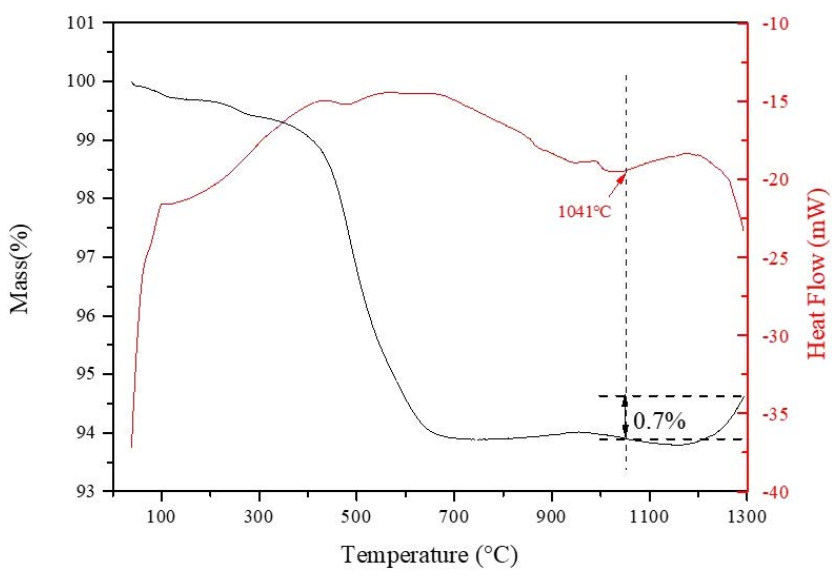

Fig. 10. The TG-DSC result of mixture of clay and $\mathrm{SiC}$ with mass ratio of 5:2. (Online version in color.)

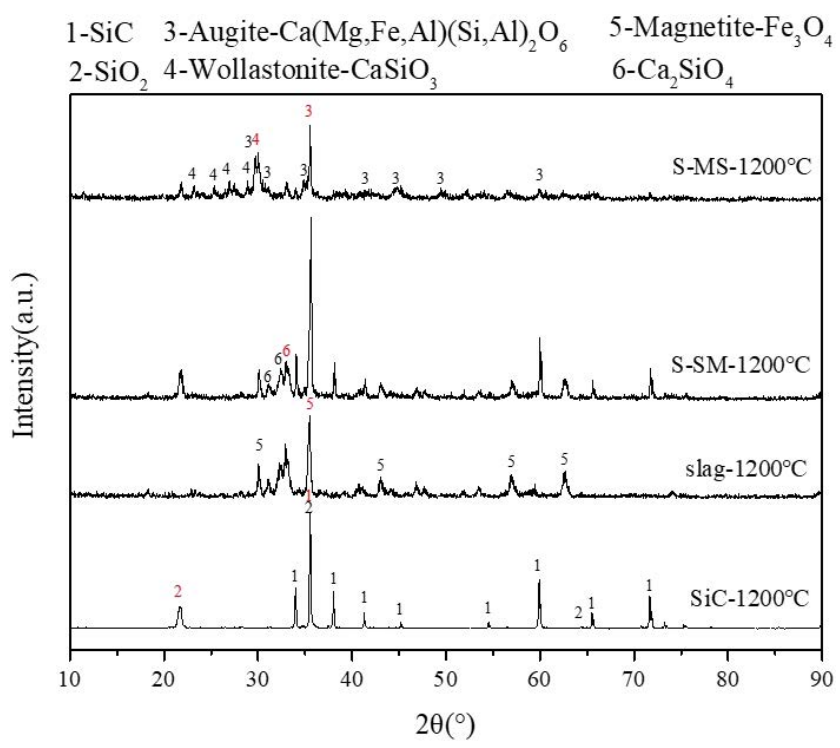

Fig. 11. The XRD result of S-MS, S-SM, slag and SiC sintered at $1200^{\circ} \mathrm{C}$, and the special red number meant the strongest or/and characteristic peak of a crystal phase. (Online version in color.)

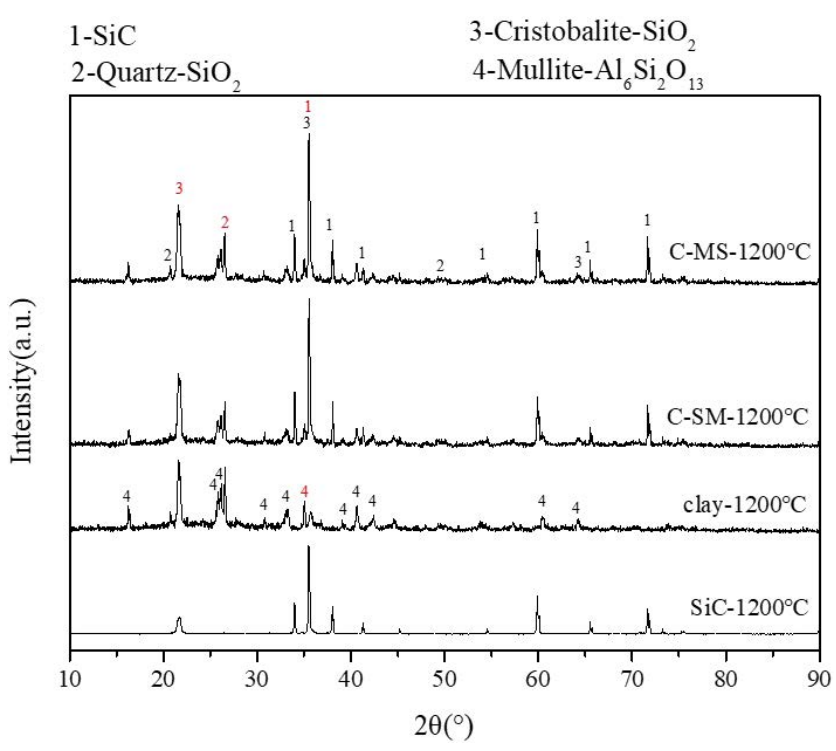

Fig. 12. The XRD result of C-MS, C-SM, clay and SiC sintered at $1200^{\circ} \mathrm{C}$, and the special red number meant the strongest or/and characteristic peak of a crystal phase. (Online version in color.) had significantly different XRD pattern with that of S-SM (mixture of sintered steel slag and sintered $\mathrm{SiC}$ at $1200^{\circ} \mathrm{C}$ ), which was the simple superimposition of patterns of sintered steel slag and sintered $\mathrm{SiC}$. While $\mathrm{C}$-MS (mixture of raw clay and $\mathrm{SiC}$ ) was sintered at $1200^{\circ} \mathrm{C}$ had a similar XRD pattern with that of C-SM (mixture of sintered clay and sintered $\mathrm{SiC}$ at $1200^{\circ} \mathrm{C}$ ).

The above results proved that there was a different foamed mechanism in steel slag ceramics with traditional clay ceramics, and a new chemical reaction between slag and $\mathrm{SiC}$ occurred during the temperature range of $1130-1220^{\circ} \mathrm{C}$.

At $1200^{\circ} \mathrm{C}$ in Fig. 11 , new phases of augite $\mathrm{Ca}(\mathrm{Mg}, \mathrm{Fe}, \mathrm{Al})$ $(\mathrm{Si}, \mathrm{Al})_{2} \mathrm{O}_{6}$ and wollastonite $\mathrm{CaSiO}_{3}$ generated in $\mathrm{S}-\mathrm{MS}$ due to reactions between $\mathrm{SiO}_{2}$ and $\mathrm{CaO} / \mathrm{Fe}_{2} \mathrm{O}_{3}$ components. However, simple mixture of sintered steel slag and $\mathrm{SiC}$ had the unreacted $\mathrm{Ca}_{2} \mathrm{SiO}_{4}, \mathrm{Fe}_{3} \mathrm{O}_{4}$ (slag-1 200 ${ }^{\circ} \mathrm{C}$ ) and $\mathrm{SiO}_{2}\left(\mathrm{SiC}-1200^{\circ} \mathrm{C}\right)$. It also proved that the new reactions between slag and $\mathrm{SiC}$ were formation of augite and wollastonite, which contributed to the different TG-DSC curves in Fig. 9.

Reaction rate (RT) is defined as mass ratio for mass gain due to oxidation of $\mathrm{SiC}$ into $\mathrm{SiO}_{2}$ to the maximum mass gain due to whole conversion of $\mathrm{SiC}$ to $\mathrm{SiO}_{2}$. Conversion of $\mathrm{SiC}$ to $\mathrm{SiO}_{2}$ results into 50 wt.\% mass gain of raw $\mathrm{SiC}$ under both $\mathrm{CO}$ or/and $\mathrm{CO}_{2}$ releasing condition. $\mathrm{RT}$ is thereby calculated by Eq. (4)

$$
R T_{T_{1}-T_{2}}=\Delta m /(0.5 \times m)
$$

where $R T_{T_{1}-T_{2}}$ is the reaction rate (\%) of SiC during temperature range from $\mathrm{T}_{1}$ to $\mathrm{T}_{2}$, and $\Delta m$ is mass gain $(\mathrm{kg})$ during the temperature due to oxidation of $\mathrm{SiC}$ according to Eq. (3) and $m$ is the mass $(\mathrm{kg})$ of $\mathrm{SiC}$.

The exothermal process of the mixture, steel slag with $\mathrm{SiC}$ completed during a relative narrow temperature range from $1130-1220^{\circ} \mathrm{C}$ in Fig. 9, and the mass gained was 10.5 wt. $\%$, which is obviously about 4 times higher than 2.2 wt. $\%$ mass gain of pure $\mathrm{SiC}$ from $1016-1300^{\circ} \mathrm{C}$ in Fig. 2(a). For

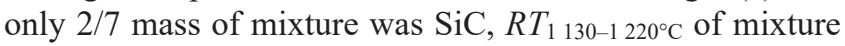
was $73.5 \%$, an order of magnitude higher not only than

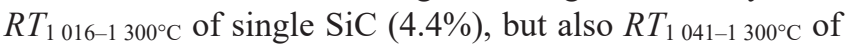
mixture between clay and $\mathrm{SiC}(4.9 \%)$. It can be seen that the addition of steel slag can promote the reaction of $\mathrm{SiO}_{2}$ on the surface of $\mathrm{SiC}$ to expose the internally unreacted $\mathrm{SiC}$ to the air for further reaction with $\mathrm{O}_{2}$ to release $\mathrm{CO}_{2}$ or $\mathrm{CO}$.

Meanwhile, The TG-DSC result of $\mathrm{SiC}$ indicate that the reaction of $\mathrm{SiC}$ begin to produce $\mathrm{SiO}_{2}$ at $1016^{\circ} \mathrm{C}$. Figure 7 showed the XRD results, and it can be inferred that quartz and rankinite were converted into anorthite and augite.

$\mathrm{Al}_{2} \mathrm{O}_{3}-\mathrm{CaO}-\mathrm{SiO}_{2}-10 \mathrm{wt} . \% \mathrm{FeO}$ phase diagram was shown in Fig. 13 As 1) most $\mathrm{Fe}$ in steel slag exists in $\mathrm{Fe}^{2+}$, and 2) $\mathrm{SiC}$ in sintering process play a reduction role, $\mathrm{Fe}$ for composition of 11.4 wt. $\% \mathrm{Fe}_{2} \mathrm{O}_{3}$ derived from XRF test is referred to be $\mathrm{Fe}^{2+}$ in ceramic S0. The red circle in Fig. 13 is the position of composition of sample $\mathrm{S} 0$ with 48.7 wt.\% $\mathrm{SiO}_{2}$, 15.3 wt. $\% \mathrm{Al}_{2} \mathrm{O}_{3}, 12.5 \mathrm{wt} \% \mathrm{FeO}$ and $18.1 \mathrm{wt} \% \mathrm{CaO}$ (Mass ratio of $\mathrm{MgO}$ was counted into mass ratio of $\mathrm{CaO}$ ). It shows that S0 fell into initial crystallization zone and located on position with eutectic temperature of $1300^{\circ} \mathrm{C}$, much lower than melting point of $\mathrm{SiO}_{2}\left(1600-1700^{\circ} \mathrm{C}\right)$. Therefore, when $\mathrm{SiO}_{2}$ layer formed on the surface of $\mathrm{SiC}$ particle, the 


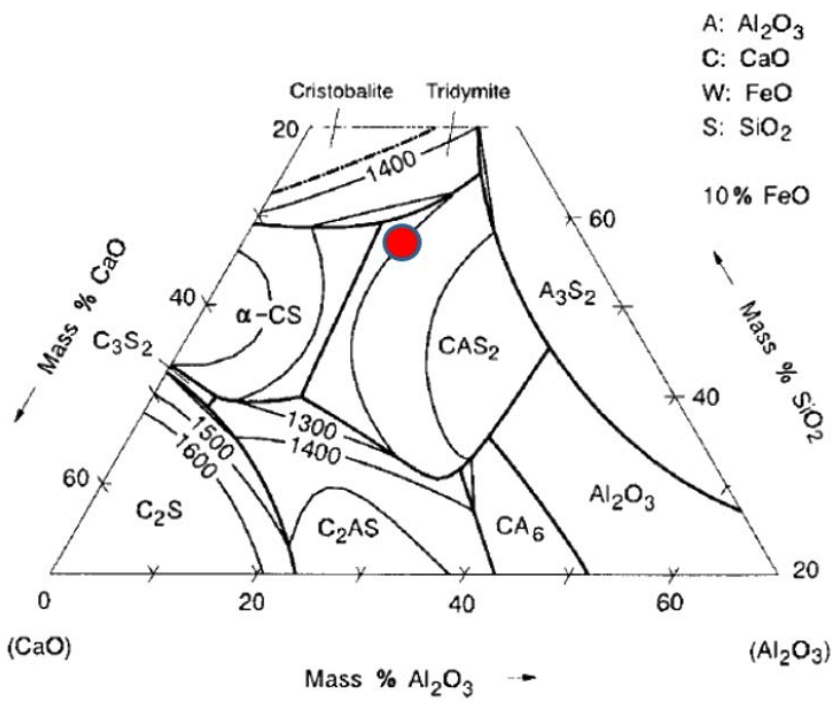

Fig. 13. $\mathrm{Al}_{2} \mathrm{O}_{3}-\mathrm{CaO}-\mathrm{SiO}_{2}-10 \mathrm{wt} . \% \mathrm{FeO}$ phase diagram, red circle is the position of composition of sample S0. (Online version in color.)

layer would be dissolved in liquid phase due to its eutectic composition between $\mathrm{SiO}_{2}$ and surrounding oxides.

As shown in Fig. 7, anorthite formed sintered at and above $1140^{\circ} \mathrm{C}$, which proved by initial crystallization zone of S0. The lower crystallization temperature of anorthite in ceramics than in Fig. 13 meant that more impurity ions including $\mathrm{Na}^{+}$and $\mathrm{K}^{+}$in ceramics had further decreased its crystallization temperature and liquidus temperature.

Meanwhile, the steel slag ceramics entered into densification stage at and above $1120^{\circ} \mathrm{C}$ as shown in Fig. 4. When sintering at and above $1130^{\circ} \mathrm{C}$, the liquid phase in ceramics increased, which provided one necessary condition for foaming of ceramics. A large quantity of gas releasing during the liquid formation stage was another necessary condition for foaming. The relative narrow exothermal peaks of mixture of $\mathrm{SiC}$ and steel slag was from $1130^{\circ} \mathrm{C}$ to $1220^{\circ} \mathrm{C}$, overlapping with the temperature stage of the liquid phase sintering. The overlap made the foaming process more effectively due to largely formation of pores from the gas and liquid phase, avoiding ineffective gas releasing at lower temperature without formation of liquid phase. Bulk density of the foamed ceramics thereby decreased rapidly with pore formation from $1130^{\circ} \mathrm{C}$ as shown in Fig. 6. The formation of pores was thereby consistent with the gas releasing behavior and its changes of properties.

\subsection{The Effect of $\mathrm{CaO}$ and $\mathrm{Fe}_{2} \mathrm{O}_{3}$ in Steel Slag on the Foaming Process}

As steel slag contains a 42.9 wt. $\mathrm{CaO}$ and 23.1 wt.\% $\mathrm{Fe}_{2} \mathrm{O}_{3}$, both $\mathrm{CaO}$ and $\mathrm{Fe}_{2} \mathrm{O}_{3}$ had significant effect on foaming process of steel slag ceramics. The above study confirmed that reactions between steel slag and $\mathrm{SiC}$ occurred above $1130^{\circ} \mathrm{C}$ which was benefit to the foaming process. However, the difference of effect between $\mathrm{CaO}$ and $\mathrm{Fe}_{2} \mathrm{O}_{3}$ on $\mathrm{SiC}$ need to be distinguished. $\mathrm{CaO}$ and $\mathrm{Fe}_{2} \mathrm{O}_{3}$ were thereby mixed with $\mathrm{SiC}$ in the molar ratio of $\mathrm{Ca}: \mathrm{Si}$ or $\mathrm{Fe}: \mathrm{Si}=1: 1$ to study the role of them in the foaming process. The results of TG-DSC and XRD were shown in Figs. 14-17.

It was shown in Fig. 14 that the addition of $\mathrm{CaO}$ decreased the oxidation temperature of $\mathrm{SiC}$ mass by $40^{\circ} \mathrm{C}$, and the

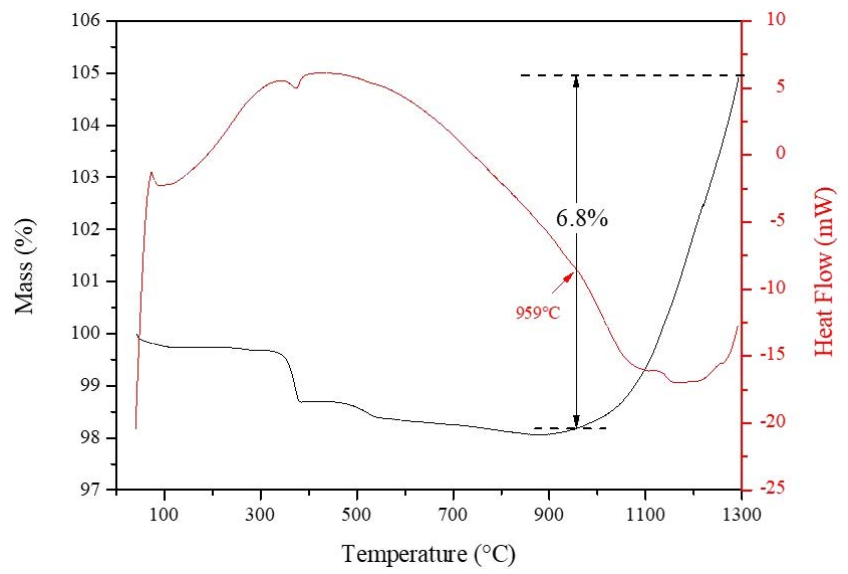

Fig. 14. The TG-DSC result of mixture of $\mathrm{CaO}$ and $\mathrm{SiC}$ with molar ratio of 1:1. (Online version in color.)

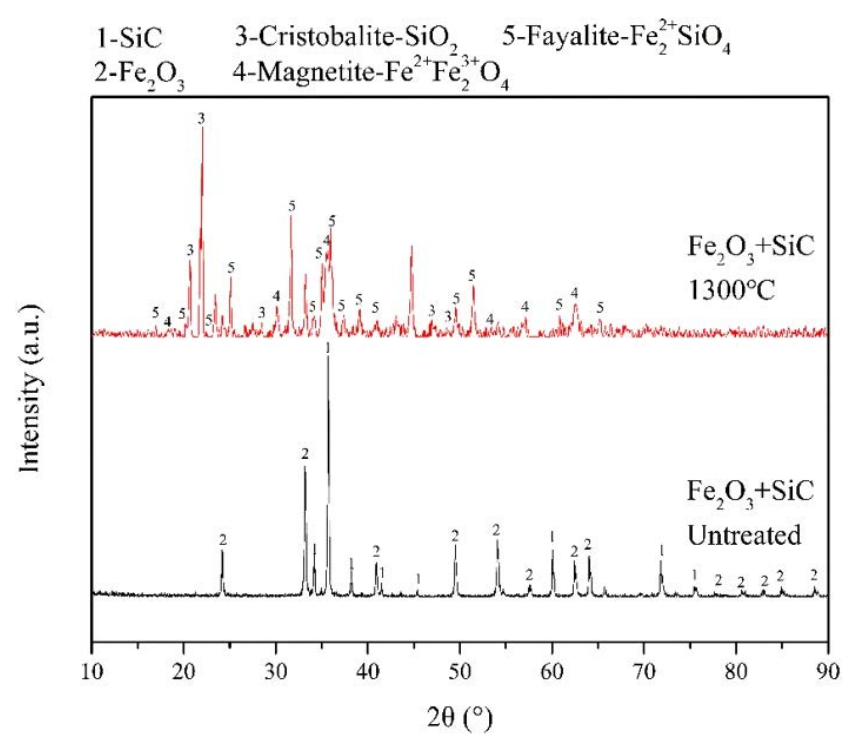

Fig. 15. The XRD result of the mixture of $\mathrm{CaO}$ and $\mathrm{SiC}$ with molar ratio of 1:1. (Online version in color.)

mass gain of $\mathrm{SiC}$ increased from $2.2 \mathrm{wt} \%$ to $6.8 \mathrm{wt} . \%$.

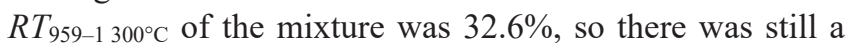
large amount of $\mathrm{SiC}$ left even if the reaction rate increased. Figure 15 showed that $\mathrm{Ca}_{2} \mathrm{SiO}_{4}$ and $\mathrm{SiO}_{2}$ are formed and the formation of $\mathrm{Ca}_{2} \mathrm{SiO}_{4}$ requires the participation of calcium and silicon, so the advance of the temperature and the increase of the reaction rate can also prove that $\mathrm{CaO}$ can effectively destroy the oxide layer on the $\mathrm{SiC}$ surface and promote the $\mathrm{SiC}$ reaction.

As shown in Fig. 16, the reaction temperature of $\mathrm{SiC}$ and $\mathrm{Fe}_{2} \mathrm{O}_{3}$ was much higher than that of $\mathrm{SiC}$ and $\mathrm{CaO}$. But the reaction was obviously concentrated in a narrow interval and completed almost within $1 \mathrm{~min}$. After that, the TG curve tended to be gentle and the final mass gain was $11 \mathrm{wt} . \%$ and $R T_{1258-1279^{\circ} \mathrm{C}}$ of the mixture was $65.9 \%$, which was equivalent to the reaction rate of $\mathrm{SiC}$.

It was noticed in Fig. 16 that during range of the exothermal reaction peak of the DSC curve from $1258-1279^{\circ} \mathrm{C}$, a decline of temperature occurred, resulting curves of both TG and DSC near $1270^{\circ} \mathrm{C}$ decreased to lower temperature and then increased continuously. The decline of temperature likely resulted from endothermic reaction of reduction of $\mathrm{Fe}_{3} \mathrm{O}_{4}$ (shown in sample slag- $1200^{\circ} \mathrm{C}$ in Fig. 11) to $\mathrm{FeO}$. As 
(a)

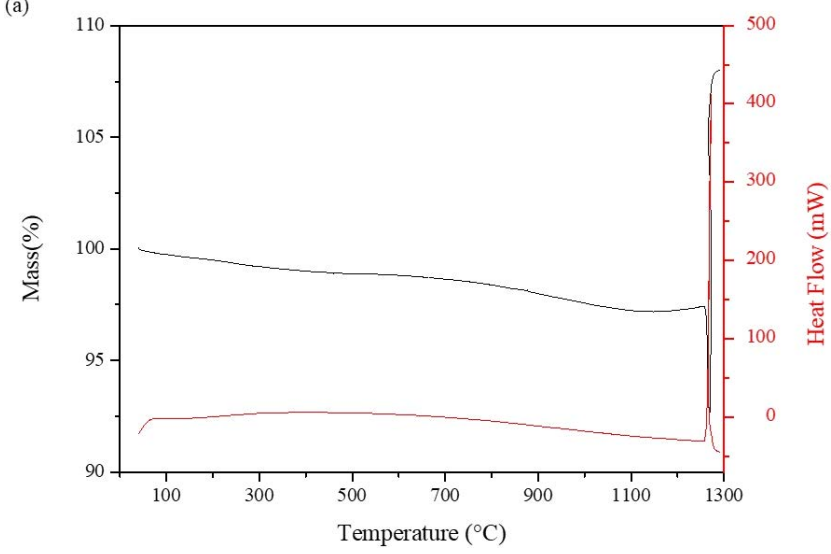

(b)

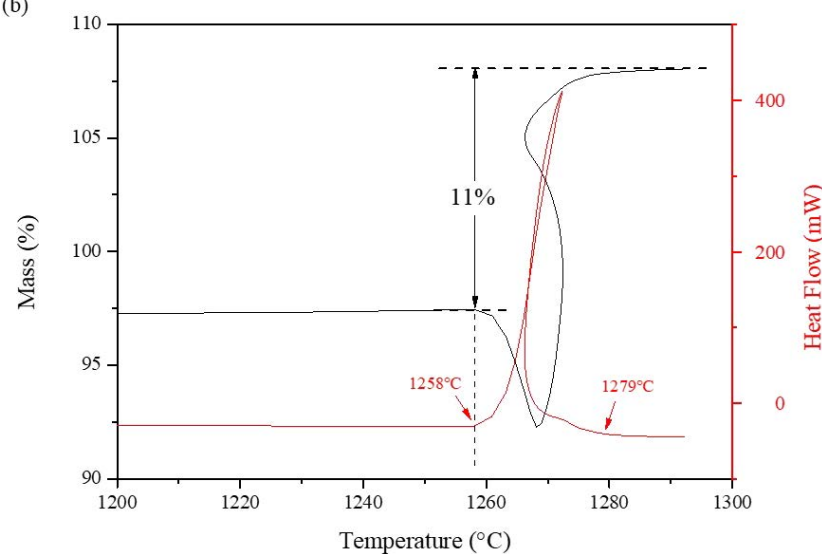

Fig. 16. The TG-DSC result of mixture of $\mathrm{Fe}_{2} \mathrm{O}_{3}$ and $\mathrm{SiC}$ with molar ratio of $1: 1$ (a) firing from $0^{\circ} \mathrm{C}$ to $1300^{\circ} \mathrm{C}$ (b) firing from $1200^{\circ} \mathrm{C}$ to $1300^{\circ} \mathrm{C}$. (Online version in color.)

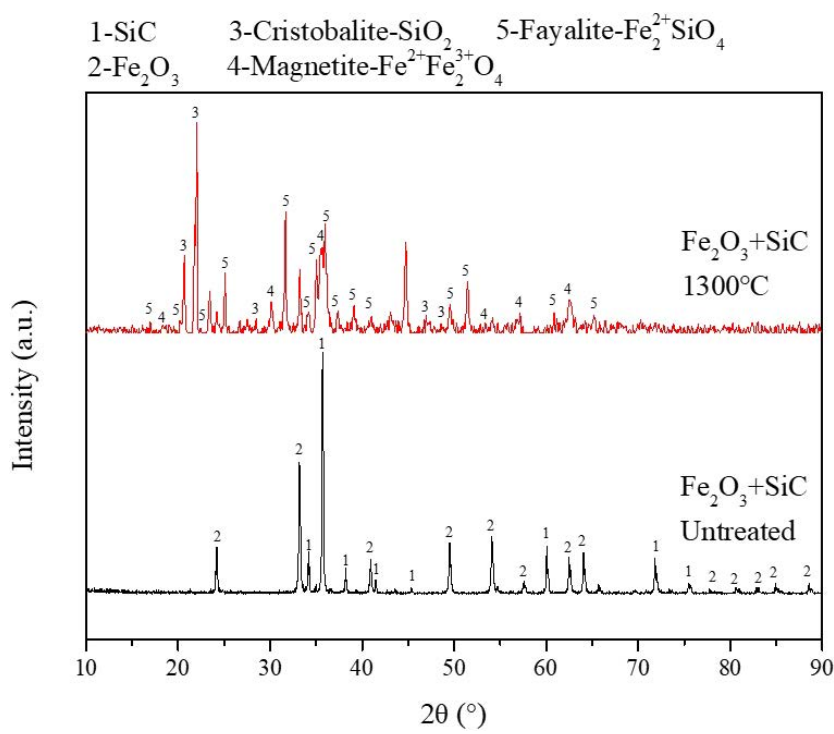

Fig. 17. The XRD result of the mixture of $\mathrm{Fe}_{2} \mathrm{O}_{3}$ and $\mathrm{SiC}$ with molar ratio of 1:1. (Online version in color.)

shown in Fig. 11, most iron in the form of $\mathrm{Fe}^{2+}$ enter into augite $\mathrm{Ca}(\mathrm{Mg}, \mathrm{Fe}, \mathrm{Al})(\mathrm{Si}, \mathrm{Al})_{2} \mathrm{O}_{6}$ in mixture (S-MS-1 200 ${ }^{\circ} \mathrm{C}$ ) after steel slag reacted with $\mathrm{SiC}$. Iron may carry oxygen as $\mathrm{Fe}^{3+}$ from the outer of reaction areas mostly during heating process and can react with $\mathrm{SiC}$ and be reduce to $\mathrm{Fe}^{2+}$ by releasing $\mathrm{O}$ to form $\mathrm{CO}$ or/ and $\mathrm{CO}_{2}$, resulting with a sharp weight loss at about $1263^{\circ} \mathrm{C}$. The reduced $\mathrm{Fe}^{2+}$ and $\mathrm{O}_{2}$ in air can further react with residual $\mathrm{Si}$ to form fayalite, which contributed to the greatly accelerated reactions during $1258-1279^{\circ} \mathrm{C}$. The XRD results in Fig. 17 showed that fayalite and magnetite were produced after sintering at $1300^{\circ} \mathrm{C}$. But there was still much $\mathrm{SiO}_{2}$ left in the product, indicating that $\mathrm{Fe}_{2} \mathrm{O}_{3}$ didn't destroy the surface oxide layer in the process of promoting the $\mathrm{SiC}$ reaction, but reacted with $\mathrm{SiC}$ quickly in a short time to avoid to forming oxide layer, so as to greatly promoting the reaction rate of $\mathrm{SiC}$.

It was shown from the results that $\mathrm{CaO}$ can easily react with $\mathrm{SiO}_{2}$ on the surface of $\mathrm{SiC}$, which made the internal $\mathrm{SiC}$ contact with air in advance. While $\mathrm{Fe}_{2} \mathrm{O}_{3}$ promoted a full oxidation of $\mathrm{SiC}$ in a high and narrow temperature range. The disadvantage of the narrow temperature was that reaction was going fast and need to be sophisticatedly controlled. Combination of the two process could make the whole reaction proceed controllable in increasing the amount of releasing gas, the initial temperature and the temperature range of foaming reaction. As previously discussed, when the results applied to the material containing a large amount of $\mathrm{CaO}$ and $\mathrm{Fe}_{2} \mathrm{O}_{3}$ such as steel slag, 0.1 wt.\% of $\mathrm{SiC}$ can achieve a desired effect, which was at least an order of magnitude lower than the amount of pure $\mathrm{SiC}$ added in the ceramics.

\section{Conclusions}

Steel slag can be used to prepare foamed ceramics. The prepared samples with 30 wt. $\%$ steel slag sintering at $1160^{\circ} \mathrm{C}$ had a density of $0.50 \mathrm{~g} / \mathrm{cm}^{3}$ and flexural strength of $2.6 \mathrm{MPa}$. Furthermore only $0.1 \mathrm{wt} \% \mathrm{SiC}$ added in the foamed ceramic is an order of magnitude lower than 1-3 wt. $\%$ of the amount of $\mathrm{SiC}$ in traditional clay foamed ceramic.

$\mathrm{SiO}_{2}$ formed from oxidation of $\mathrm{SiC}$ had reacted with $\mathrm{CaO}$ and $\mathrm{Fe}_{2} \mathrm{O}_{3}$ component derived from steel slag to generate new minerals, augite and anorthite.

Compared with the traditional foamed ceramic, reaction rate of $\mathrm{SiC}$ mixing with steel slag from $1130^{\circ} \mathrm{C}$ to $1220^{\circ} \mathrm{C}$ significantly increased to $73.5 \%$, which is an order of magnitude higher than $4.9 \%$ of reaction rate of $\mathrm{SiC}$ mixing with clay from $1016-1300^{\circ} \mathrm{C}$. Temperature range of oxidation reaction of $\mathrm{SiC}$ was concentrated into $1130-1220^{\circ} \mathrm{C}$ from $1016^{\circ} \mathrm{C}$ to above $1300^{\circ} \mathrm{C}$ and overlapped with the range of the liquid phase sintering of ceramics, resulting in a more effectively foaming process to generate more pores from the concurrence between gas and liquid phase.

Addition of steel slag into $\mathrm{SiC}$ has a great application prospect in preparation of low cost foamed ceramics.

\section{Acknowledgment}

This work has been financially supported by the National Natural Science Foundation of China (No. 51674029) and Major Science and Technology Innovation Engineering Projects of Shandong Province (No. 2019JZZY010404).

\section{REFERENCES}

1) World Steel Association: Global crude steel output increases by $3.4 \%$ in 2019 , https:/www.worldsteel.org/zh/media-centre/pressreleases/2020/Global-crude-steel-output-increases-by-3.4--in-2019. html, (accessed 2020-01-27) (in Chinese).

2) Y. Li and W. B. Dai: J. Clean. Prod., 175 (2018), 176

3) W. D. Fan, Q. W. Yang, B. Guo, B. Liu and S. G. Zhang: Rare Met., 
37 (2018), 413

4) L. H. Zhao, Y. Li, Y. Y. Zhou and D. Q. Cang: Mater. Des., 64 (2014), 608.

5) Y. Li, Y. P. Ren, D. J. Pei, H. J. Sheng, Y. D. Yi and D. Q. Cang: ISIJ Int., 59 (2019), 1723.

6) A. Hayashi, T. Watanabe, R. Kaneko, A. Takano, K. Takahashi, Y. Miyata, S. Matsuo, T. Yamamoto, R. Inoue and T. Ariyama: ISIJ Int., 53 (2013), 1894.

7) M. X. Tu, H. X. Zhao, Z. Lei, L. N. Wang, D. S. Chen, H. D. Yu and T. Qi: ISIJ Int., 55 (2015), 2509.

8) D. Mudersbach, P. Drissen and H. Motz: Proc. 2nd Int. Slag Valorisation Symp., KU Leuven, Leuven, (2011), 299.

9) C. M. Du, X. Gao, S. Ueda and S. Y. Kitamura: ISIJ Int., 58 (2018), 833.

10) Z. M. Wu, J. F. Xu, H. X. Zhang and Y. Zhang: New Build. Mater. 37 (2010), 1 (in Chinese)

11) E. Bernardo, R. Castellan, S. Hreglich and I. Lancellotti: J. Eur. Ceram. Soc., 26 (2006), 3335.

12) R. Ji, Z. T. Zhang, Y. He, L. L. Liu and X. D. Wang: Constr. Build. Mater, 85 (2015), 119

13) L. Yan, M. K. Tian, J. L. Qin, J. Wang, B. Zhuang and W. L. Tao: China Ceram., 51 (2015), 58 (in Chinese).

14) Y. Li and Y. Zhang: Refract. Lime, 34 (2009), 53 (in Chinese).

15) D. Yang, H. Y. Du, S. H. Li and R. Xu: Rare Met. Mater. Eng., 40 (2011), 25 (in Chinese).

16) C. M. Riley: J. Am. Ceram. Soc., 34 (1951), 121

17) C. J. Shi and J. S. Qian: Resour. Conserv. Recycl., 29 (2000), 195.

18) A. V. Gorokhovsky, J. I. Escalante-Garcia, E. Sanchez-Valdes, I. N Burmistrov and D. V. Kuznetsov: Ceram. Int., 41 (2015), 13294.
19) E. Karamanova, G. Avdeev and A. Karamanov: J. Eur. Ceram. Soc., 31 (2011), 989.

20) X. B. Ai, Y. Li, X. M. Gu and D. Q. Cang: Adv. Appl. Ceram., 112 (2013), 213

21) Y. K. Wang, Y. Li, Y. Z. Wang and D. Q. Cang: Energy Metall. Ind., 37 (2018), 48 (in Chinese)

22) L. Jiang: M. S. thesis, Chongqing University, (2015), http:// kreader.cnki.net/Kreader/CatalogViewPage.aspx?dbCode $=$ cdmd $\&$ filename $=1015967509$. nh $\&$ tablename $=$ CMFD201601 $\&$ compose $=$ \&first $=1$ \&uid $=$, (accessed 2015-05-01) (in Chinese)

23) H. Wang, Z. W. Chen, L. L. Liu, R. Ji and X. D. Wang: Ceram. Int., 44 (2018), 10078.

24) C. C. Jiang, S. F. Huang, G. Z. Li, X. Z. Zhang and X. Cheng: Ceram. Int., 44 (2018), 3469.

25) Y.L.Zhang: M. S. thesis, South China University of Technology,(2014), http://kreader.cnki.net/Kreader/CatalogViewPage.aspx?dbCode $=$ cdmd\&filename $=1014064330$. nh\&tablename $=$ CMFD201501\& compose $=\&$ first $=1 \&$ uid $=,($ accessed 2014-06-01) $($ in Chinese $)$.

26) Q. D. Wu and Y. F. Tong: Ceram. Sci. Art, 36 (2002), 7 (in Chinese).

27) X. A. Xi, L. F. Xu, A. Z. Shui, Y. M. Wang and M. Naito: Ceram. Int., 40 (2014), 12931

28) GB/T 6730.6-2016: 2016, Iron ores--Determination of metallic iron content--Ferric chloride-sodium acetate titrimetric method (in Chinese).

29) GB/T 6730.5-2007: 2007, Iron ores--Determination of total iron content-Titanium (III) chloride reduction methods (in Chinese)

30) GB/T 6730.8-2016: 2016, Iron ores--Determination of iron (II) content--Potassium dichromate titrimetric method (in Chinese). 